\title{
THE USE OF LOGICO MEDIA TO ENHANCE STUDENTS' SPEAKING SKILLS IN REPORT TEXTS
}

\author{
Syaifullah ${ }^{1}$, Kristini ${ }^{2}$ \\ ${ }^{1}$ Balai Diklat Keagamaan Banjarmasin \\ ${ }^{2}$ MTs Negeri 1 Kotawaringin Timur Sampit \\ 1abuerly@gmail.com; ${ }^{2}$ christinsmart@gmail.com
}

\author{
https://doi.org/10.36052/andragogi.v9i2.248 \\ Diterima: 11 Oktober 2021 | Disetujui: 21 November 2021 | Dipublikasikan: 31 Desember 2021
}

\begin{abstract}
Abstrak
Penelitian tentang penggunaan media logico untuk meningkatkan keterampilan berbicara siswa dalam report text untuk siswa Madrasah Tsanawiyah masih jarang dilakukan. Oleh karena itu, tujuan dari penelitian ini adalah untuk mendeskripsikan dan mengevaluasi keefektifan media logico dalam meningkatkan kemampuan berbahasa Inggris Report Text pada siswa kelas IX Ruang 1 MTs Negeri 1 Kotawaringin Timur. Jenis penelitian ini adalah Penelitian Tindakan Kelas yang dilaksanakan dalam dua siklus. Setiap siklus terdiri dari 3 kali pertemuan dengan prosedur penelitian dimulai dari perencanaan, pelaksanaan, observasi, dan refleksi. Subjek penelitian ini adalah 31 siswa kelas IX Ruang 1 MTs Negeri 1 Kotawaringin Timur. Data dalam penelitian ini diperoleh melalui tes, observasi, wawancara dan dokumentasi. Data tersebut kemudian dianalisis secara deskriptif, kuantitatif, dan kualitatif. Temuan penelitian ini menunjukkan bahwa Logico Media membantu siswa Kelas IX Kelas IX MTs Negeri 1 Kotawaringin Timur dapat meningkatkan keterampilan berbicara dan hasil belajar mereka. Keterampilan berbicara bahasa Inggris meningkat dari 19,84 persen menjadi 85,64 persen pada akhir siklus 2, sedangkan hasil belajar klasikal mencapai 100\% dengan persentase peningkatan dari 48,39 persen menjadi 100 persen pada siklus 2 .
\end{abstract}

Kata Kunci: Keterampilan Berbicara, Report Text, Logico Media

\begin{abstract}
Researches on the use of logico media to improve students' speaking skills in report text for high school students is still rarely done. Therefore, the purpose of this research is to describe and evaluate the effectiveness of logico media in improving English proficiency in Report Text in class IX students of Room 1 MTs Negeri (State Islamic junior high school) 1 Kotawaringin Timur. This type of research is Classroom Action Research which is carried out in two cycles. Each cycle consists of 3 meetings with research procedures starting from planning, implementing, observing, and reflecting. The subjects of this study were 31 students of Class IX Room 1 MTs Negeri 1 Kotawaringin Timur. The data in this study were obtained through tests, observations, interviews, and documentation. The data were then descriptively, quantitatively, and qualitatively analyzed. This study's findings show that Logico Media helps students in Room 1 of MTs Negeri 1 Kotawaringin Timur's Class IX improve their speaking skills and learning outcome. English-speaking skills increased from 19.84 percent to 85.64 percent by the end of cycle 2, while classical learning outcomes reached 100\% with a percentage increase from 48.39 percent to 100 percent by cycle 2 .
\end{abstract}

Keywords: Speaking English, Report Text, Logico Media

This work is licensed under a Creative Commons Attribution-NonCommercial 4.0 International License 


\section{INTRODUCTION}



he ability of the learner to speak is a good indicator of success in learning a language at first (Zuhriyah. M.,2017),

(Srinivas, Parupalli Rao, 2019). However, speaking a foreign language, particularly English, is extremely difficult for beginners. There are numerous reasons why they have difficulty in speaking, including a lack of ideas to tell, a lack of vocabularies to express the ideas, a lack of opportunities to speak, and a lack of an engaging teaching method that can motivate them to speak (Signes Gregori, 2015).

Similar to the problems above, as English teachers, the writers recognize that the students are having difficulties learning to speak. As a result of these problems, pupils have low levels of enthusiasm for learning English, and their capacity to express themselves and develop ideas orally is severely limited. This condition was discovered through observations made during speaking skills learning activities and through the evaluation of student learning outcomes in the speaking skills test, which revealed that the majority of the 31 students got scores of 60.50 .

In reference to the problems mentioned above, the writers conducted a reflection and critical assessment effort with the assistance of several colleagues. Several indications were discovered that were assumed to be the cause of students' low learning outcomes in English speaking skills, In the first place, the teacher's approach to the learning process emphasizes textbook content, which leaves pupils in a passive role. Students are bored in class because the teacher uses traditional teaching tools like books and chalkboards. As a result, teachers should make use of a variety of media when instructing students on the English language. For this reason, some efforts are needed to improve the student's speaking skill in report texts.

There are some previous researches investigated the student's ability in understanding report texts; (Rahmi \& Ratmanida, 2014), (Yulianti \& Setiawan, 2019), (Muftiani, 2015). Besides, there are some researches related to the students writing ability in writing report texts; (Djumingin, 2017), (Conny \& Devita, 2019), (Batubara et al., 2021),(Rizky \& Zainil, 2021),(Azizah, 2019), (Pujianto et al., 2014). Based on the search results on Google Scholar, most of the researches conducted are related to report texts for reading skills and report texts for writing skills. There are very few studies that examine the improvement of students' speaking skills in report texts. Therefore, the writers are interested in researching how to improve students' speaking skills in report text using Logico media.

As an education game, Logico helps students improve their vocabulary mastery (Purnamu \& Priyana, 2020).They further stated that learning English is more fun when it is done through games. Games encourage students to initiate speaking in English, provide plenty of opportunities for them to speak as often as possible, and encourage them to focus on fluency rather than accuracy. Students may have fun while thinking about the answers in this game while they play because it is simple and easy to use.

The use of Logico media is expected to improve the students English speaking skills. Therefore, this study aims to describe and analyze students' activeness and learning outcome during the learning process in improving English speaking skills in Report Text through Logico media in class IX students of Room 1 MTs Negeri 1 Kotawaringin Timur Central Kalimantan Indonesia.

Speaking is a language skill that allows people to connect with one another and learn about one another's lives. Speaking is also a way for people to communicate their innermost thoughts, feelings, intentions, messages, and ideas. Many things' people can do through talking, for example asking questions, asking for something, expressing joy 
or sadness, and seeking information directly from other people (Srinivas, 2019).

The idea of speaking may be worth exploring. In order to communicate effectively, students must be able to speak fluently and clearly. For the most part, talking is imitation and reproduction, which allows students to practice communication patterns (Becker \& Roos, 2016). When it comes to spoken language, speaking plays a crucial role in conveying messages that differ from written language.

Many strategies can be utilized when teaching young learners how to communicate effectively through speech. Teachers of English can use role-playing, videos, jazz chant, digital storytelling, games, and repetition in classroom activities (Florentina Robert \& Syahtia Pane, 2020). Language games are an effective teaching tool because they help students improve their oral communication skills so they can talk to and interact with their classmates in their target language (Owen et al., 2019). He came to the conclusion that learners were motivated to learn the target language by playing language games. Communicative activities have been shown to improve students' communication skills.

Based on the statement above, it can be stated that speaking is a language ability that enables people to connect with one another and learn about one another's lives. Speaking enables people to communicate their deepest thoughts, feelings, intentions, messages, and ideas. Games can help students improve their communication skills. One type of game that is emerging as an alternative is Logico media.

One of the texts studied in English class is the Report Text. This text provides general information about things, people, and locations. This annoying text is nearly identical to descriptive text, making it difficult for students to tell the two apart. It may reveal natural phenomena like living or non-living things, as well as social phenomena like technology, economic issues, parliament, and political parties (Dinamika \& Hanafiah, 2019).

According to Griffith (2000), a Report Text is a piece of writing that presents information about a subject matter exactly as it is found in real life. It is as a result of careful, methodical examination and research. Similarly, Haryanto (2012) stated that the purpose of a report text is to convey information about something in its current state, as a systematic observation or analysis. Classification and description make up the report text's structure. The classification section introduces the reader to the subject matter. The description, on the other hand, includes elements like parts, quality, and behavior to help explain the subject matter. A simple past tense is used instead of the present tense to describe extinct items, animals, and plants.

In light of the description above, we can conclude that report text is used to convey information about something in its current state, as a systematic observation or analysis. It is the goal of this research to find out how well students can communicate information from a report text orally.

Logico is a teaching aid that is a medium for learning English. Finken Verlag (1993) stated that Logico is learning media developed in Germany since 1993. This device is made up of a board and a number of colorful and eyecatching sheets of paper. This educational game's interface is simple to use, so students have a good time playing it while learning to think critically about the answers to different questions.

Logico has two types, namely: Logico Picolo and Logico Maximo. Logico Picolo is more appropriate for beginner language learners. It includes a wide range of English questions, general knowledge, and other topics presented in pictures and words, ranging from easy to more difficult levels (Prastyawati, 2020). The main target of this package is to instill students' sensitivity to the concepts of understanding questions and mastering vocabulary. The main 
target is that students are able to enrich their English vocabulary. One set of logico consists of a book, question and answer sheets and a Logico board.

Logico piccolo is designed using attractive colors and images. Windura (2008: 3 ) said that the right media in learning should be able to cover the right brain and left brain. Only by involving the right brain and left brain, the learning process will be more effective and fun. The left brain is used for language, numbers, analysis, logic, sequence, calculation, and detail. While the right brain is more likely to be used in creativity, conceptual, art, music, images, dimensions, emotions, daydreaming, and imagination.

Anggun Tri Sukmawati (2015) said that something related to language activities, namely writing, reading, speaking, and listening is to use the left brain. Left brain nature of memory is short term. On the other hand, when asked to retell the contents of a particular book in just 2 minutes, the conceptual power is at work, and is using the right brain.

Logico Maximo is specially designed to introduce grammar to students who are at a higher level than logico picolo. The main target is to train students to be proficient, think logically, critically, carefully, creatively in understanding question sentences and solving problems. The result of learning this logic is that students are able to communicate both orally and in writing.

This logic has several parts such as:

1. Logico consists of a display board and several packs of paper containing sheets of illustrated questions.

2. On the board made of plastic there is a gap that can be inserted question sheets.

3. On the bottom and right side of the board there are paths to slide the colorful rounded pieces that are attached.

4. The sheet of paper contains the questions on one side, and the answers on the other side
5. On the first side (question) there are cases (on the left) and answer choices (on the right).

6. Questions can also be in the form of links between the pictures on the left and right

g. All pictures or questions are marked with a color circle that matches the color of the pieces on the display board

The folowings are the ways to apply Logico in class.

1. Insert the question sheet in the gap of the board through the top side

2. Make sure all the color chips on the board are at the bottom

3. Pay attention to the suitability of the color of the chip with the color of the circle in the question image (identification process). The color of the chips on the board represents the questions marked with the samecolored circle

4. Find the right answer (relationship) for each question with the available answer choices

5. Move the color chip representing the question to the side of the correct answer.

6. And so on, until all of the bottom pieces have shifted to the right and all of the questions have been answered.

7. To check the answers, remove the question paper from the board, turn it over, and put it back in. The second side of the sheet of paper contains the answers to the questions, which are marked with colored circles on the right in the correct order.

8. If the order of the color chips that have been shifted to the right of the board (from top to bottom) is exactly the same as the order of the colored circles on the answer sheet, it means that all the questions have been solved correctly (Anggun Tri Sukmawati (2015).

\section{RESEARCH METHODS}

The subjects of this study were students of class IX Room 1 odd semester MTs Negeri 1 
Kotawaringin Timur in the $2019 / 2020$ school year, with a total of 31 students consisting of 9 male students and 22 female students. This research was conducted at Madrasah Tsanawiyah (MTs) Negeri 1 Kotawaringin Timur, which is located at Jalan Pelita Barat No. 2 Sampit Tel. (0531) 21833, Mentawa Baru Hilir Village, Mentawa Baru District, Ketapang, East Kotawaringin Regency, Central Kalimantan Province.This research was carried out for 2 months starting with pre-action activities, from January to February 2020 until the seminar on the results of Classroom Action Research. As stated by Suharsini Arikunto (2008) explaining that classroom action research activities include cycles consisting of planning (planing), implementing (acting), observing (observing) and reflecting (reflecting). The results of one cycle are used to determine activities in the next cycle, until the problem can be solved with the strategy used. The stages involve planning, implementation, observation, and reflection.

\section{FINDING AND DISCUSSION}

\section{Pre-Cycle}

Based on the results of observations of student activity during the learning process before the classroom research action was carried out, it showed that students' attitudes did not help the teacher in achieving the learning objectives that were set and to be achieved. Students are very passive, lack discipline and do not know how to interact or cooperate with teachers or fellow students. The observer's observations on student activity in this pre-action only reached $65.96 \%$. Student behavior like this is a major obstacle in improving student achievement in speaking English. Therefore, it must be improved by using appropriate learning media that can activate students.

Student learning outcomes in improving English speaking skills before classroom action research was carried out were also still low. This can be seen from the results of the pre-test of speaking English. The results are as follows in the table.

\begin{tabular}{|l|c|c|}
\multicolumn{3}{|c}{ Table 1. Results of Pre-Action } \\
\hline \multicolumn{1}{|c|}{ Criteria } & Average Score & Description \\
\hline Learning Result & $65,80 \%$ & $\begin{array}{c}\text { At this stage there } \\
\text { are } 15 \text { students } \\
\text { below the standard }\end{array}$ \\
\hline $\begin{array}{l}\text { Classical } \\
\text { Improvement }\end{array}$ & $51,61 \%$ & \\
\hline
\end{tabular}

Based on the table above, the results of the pre-action assessment show that the value of learning outcomes in improving speaking skills reaches an average of $65.80 \%$, while the value of classical completeness only reaches $51.61 \%$. This value is very low and lacking. This means that the mastery level of learning English, especially students' speaking skills, is still below the minimum completeness criteria (85\%) from the set. This condition must be addressed immediately to improve the problems faced by students in improving speaking skills by taking an action in the form of classroom action research. And then the authors carry out classroom action research as much as 2 cycles.

\section{Result of Cycle 1}

Class action research in cycle 1 was carried out in 3 meetings. The first meeting was held on January 13,2020 , the second meeting was held on January 15, 2020, while the third meeting was held on January 20, 2020. This third meeting was the last meeting and the final assessment of cycle 1 was carried out on students' speaking skills in English through Logico media. There are two things that are improved in this study, namely student activity during the learning process and student learning outcomes in improving English speaking skills through Logico media. The results of the research are as follows:

The observer's observations on student activity during the learning process in the first cycle of classroom action research have increased slightly. There are some students who are moderately active, some students are disciplined in following the lesson and don't go in and out of class because they are bored and interactions between teachers and fellow 
friends are also visible. This can happen because the author's teacher has been able to manage the class well. Learning using logico media attracts students' attention.

The results of the first cycle class action research in improving English speaking skills with Logico media after students participated in learning for 2 meetings, then at the third meeting on January 20, 2020 an Englishspeaking test was carried out. The results can be seen in the following table.

\begin{tabular}{|l|c|c|}
\hline \multicolumn{3}{|c|}{ Table 2 Cycle 1 Result } \\
\hline \multicolumn{1}{|c|}{ Criteria } & Average Score & Description \\
\hline Learning Result & $69,19 \%$ & $\begin{array}{c}\text { At this stage there } \\
\text { are 8 students } \\
\text { below the } \\
\text { standard }\end{array}$ \\
\hline $\begin{array}{l}\text { Classical } \\
\text { Improvement }\end{array}$ & $74,19 \%$ & \begin{tabular}{c} 
stand \\
\hline
\end{tabular}
\end{tabular}

Based on the table above, the results of the cycle 1 assessment show that the value of learning outcomes in improving speaking skills reaches an average of $69.19 \%$, while classical completeness only reaches $74.19 \%$. This proves that there has been a significant increase from the previous $3.39 \%$ from the pre-action results (65.80\%) to cycle 1 (69.19\%). However, this result is still below the specified indicator, namely completeness of at least $85 \%$ and the average student score of 80 . Based on the data, there are still 8 students whose scores are below the KKM, meanwhile from the five speaking skills assessment criteria there are still several aspects such as structure, fluency and pronunciation of students whose scores are low and need improvement. For this reason, further action is needed to the next cycle.

\section{Result of Cycle 2}

Classroom action research in cycle 2 was carried out for 3 meetings. The 1 st meeting was held on January 27,2020 , the 2 nd meeting was held on January 29, 2020 and the 3rd meeting was held on February 3, 2020. This 3rd meeting was the last meeting to carry out a student speaking test to get a clearer picture of improvement. learning outcomes, especially English-speaking skills. The results of the action of cycle 2 are as follows. The second cycle of action both at the 1 st and 2 nd meetings has shown a very significant increase in student activity. All students are very enthusiastic in participating in the learning process. Students compete to be active both to answer questions, ask questions, deliver performance, and discuss in groups. Students also appear disciplined when the teacher gives assignments to enter groups and discuss, student interactions between fellow students and teachers are very well established. The learning situation in the classroom is really well managed and interesting so that in cycle 2 this will help the author to achieve the goals that have been determined. Observer observation data showed an increase in student activity in cycle 2 of $86.12 \%$. These results have exceeded the specified indicators compared to pre-action and cycle 1.

The results of the second cycle of classroom action research on speaking skills after students took part in the learning process for 2 meetings, then at the third meeting on February 3, 2020 an English-speaking skills test was carried out with Logico media. The results can be seen in the following table:

Table 3. Cycle 2 Result

\begin{tabular}{|l|c|c|}
\hline \multicolumn{1}{|c|}{ Criteria } & Average Score & Description \\
\hline Learning Result & $85.64 \%$ & $\begin{array}{c}\text { At this stage } \\
\text { there all students } \\
\text { are above of the } \\
\text { minimal standard } \\
\text { Classical }\end{array}$ \\
Improvement & $100 \%$ \\
\hline
\end{tabular}

Based on the table above, the results of the second cycle of assessment show that the value of learning outcomes to improve students' English-speaking skills through Logico media reaches an average of $85.64 \%$, while the classical completeness score reaches $100 \%$. These results prove that there is an increase in students' English-speaking skills which is very significant by $16.45 \%$ compared to the results in the previous action, namely from cycle 1 (69.19\%) to cycle 2 (85.64\%). This result has met the achievement of learning completeness of at 
least $85 \%$ with an average student score of 80 according to the established success indicators. All aspects in the assessment of students' speaking skills (content, structure, vocabulary, fluency and pronunciation) have been achieved and improved. This means that Logico media is very appropriate to be used to improve students' speaking skills in English, especially for class IX students in Room 1 of MTs Negeri 1 Kotawaringin Timur. This media has helped students in mastering a lot of vocabulary, so that students already have the capital of words to speak. Seeing these results, the author is satisfied and does not need to continue to the next cycle.

Below are the overall results of improving English learning outcomes in improving students' speaking skills through Logico media from each action to the next.

Table 4. Result of the Overall Cycles

\begin{tabular}{|l|c|c|l|}
\hline \multirow{2}{*}{ Criteria } & \multicolumn{3}{|c|}{ Average Score } \\
\cline { 2 - 4 } & Pre-Cycle & Cycle 1 & \multicolumn{1}{|c|}{ Cycle 2 } \\
\hline Learning Process & $65,96 \%$ & $79,35 \%$ & $86,12 \%$ \\
\hline Percentage & $13,39 \%$ & $6,77 \%$ & $20,16 \%$ \\
\hline Learning Result & $65,80 \%$ & $69,19 \%$ & $85,64 \%$ \\
\hline Percentage & $3,39 \%$ & $16,45 \%$ & $19,84 \%$ \\
\hline Classical Improvement & $51,61 \%$ & $74,19 \%$ & $100 \%$ \\
\hline Percentage & $22,58 \%$ & $25,81 \%$ & $48,39 \%$ \\
\hline
\end{tabular}

The following is a graph of the percentage increase in activity during the learning process, learning outcomes and learning completeness from pre-action to cycle 1, cycle 1 to cycle 2 and from pre-action to cycle 2 .

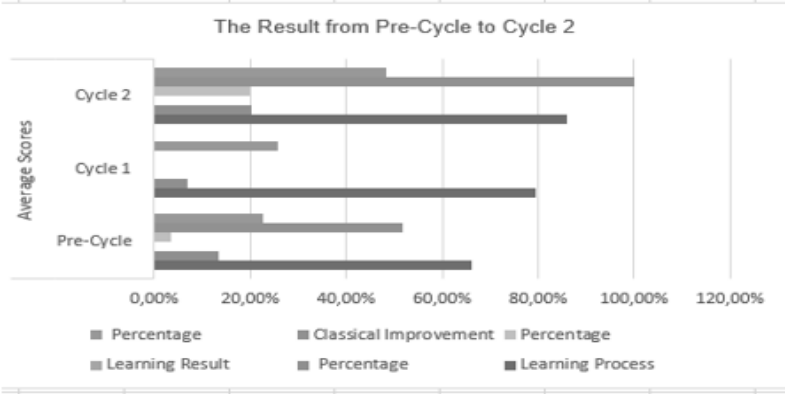

Paying attention to the graph above shows that there really is a significant increase in student learning outcomes in improving English speaking skills through Logico media from pre-action to cycle 1 , from cycle 1 to cycle 2 from pre-action to cycle 2 . Final results of action research the class is in cycle 2 and the result increase is active students during the learning process increased by $20.16 \%$, learning outcomes increased by $19.84 \%$, and classical learning completeness reached $48.39 \%$.

\section{Discussion}

Based on observations from classroom action research conducted for 2 cycles and each cycle consisting of 3 meetings, it has been proven that learning English using Logico media is very effective and appropriate to improve English speaking skills in Report text material for class IX students in Room 1. This is evident from the analysis of the observational data obtained from the observer to the teacher and students during the learning process from each action to the next action. It shows that the author's teacher has prepared himself with all learning tools and research instruments properly and completely so that the learning process in the classroom during the action running smoothly.

The attitudes and behavior of students during their actions were initially very passive, lacking discipline and there was no visible interaction between teachers and fellow students, after repeated actions, these attitudes changed to become more active, enthusiastic, disciplined, like to ask questions and collaborate between teachers and fellow students. The students are happy and fun to learn by using Logico media, because this media is very easy to use and students feel at home to learn while playing it. The student activeness experienced a very significant increase from pre-action (65.96\%) to cycle 1 (79.35\%) of $13.39 \%$, cycle $1(79.35 \%)$ to cycle 2 (86.12\%) increased by 6.77 and from preaction (65.96 \%) to cycle 2 (86.12\%) increased by $20.16 \%$. This means that students are able to condition themselves well in every action.

Based on the observations, the learning process has increased from action to action. In addition, students seemed happy, cheerful, enthusiastic and fun learning English using 
Logico media. This media is very appropriate to help students improve speaking skills, because this media is equipped with interesting colorful pictures and easy English questions so that it stimulates students' left and right brain work well and motivates students' learning in discussing and doing English questions through Logico media. Meanwhile, the author's teacher is also very enthusiastic in guiding and assisting students in learning and doing assignments using Logico media. And with this logico media, the five aspects that become the criteria for assessing speaking skills (content, structure, vocabulary, fluency and pronunciation) can be mastered and improved well by the students.

The above success has influenced the improvement of students' English learning outcomes, especially speaking skills, this is evident from the results of the percentage of learning outcomes from pre-action $(65.80 \%)$ to cycle $1(69.19 \%)$ increased by $3.39 \%$, from cycle 1 (69.19\%) to cycle 2 (85.64\%) increased by $16.45 \%$ and increased learning outcomes from Pre-Action (65.80\%) to Cycle 2 (85.64\%) by $19.84 \%$. While the classical mastery of learning also increased between pre-action (51.61\%) to cycle I (74.19\%) by $2.58 \%$, from cycle I $(74.19 \%)$ to cycle $2(93.54 \%)$ of $25.81 \%$ and from preaction (51.61\%) to cycle 2 (100\%) of $48.39 \%$. $100 \%$ completeness at the end of cycle 2 has shown an increase in students' English speaking skills, meaning that they have reached the indicators of success of the action set, namely the minimum completeness criteria of $85 \%$ and the average student score of 80 .

Regarding the success of classroom action research in improving students' Englishspeaking skills through Logico media, the authors can conclude that the advantages of the media are as follows (1) helping students in mastering English vocabularyb. Motivate students to learn independently, think logically and critically and develop imagination, (2) stimulates students' left and right brain work because this media is equipped with colorful educational pictures and interesting English questions that help students easily express ideas, ideas and opinions, (3) provide opportunities for students to study alone or in groups, and (4) helping students in solving problems and solving them on their own when there are difficulties.

A series of Classroom Action Implementation (CAR) activities that have been carried out with the title Improving English Speaking Skills for Report Text Materials through Logico Media for Class IX students in Room 1 of MTs Negeri 1 Kotawaringin Timur have succeeded in answering the problem formulation and research objectives to be achieved.

\section{CLOSING}

\section{Conclusion}

As a result of the findings and discussions, it can be concluded that the use of Logico media in the teaching of speaking skills in report texts can improve the students English-speaking skills, student engagement, and learning outcomes. Finally, students' command of the English speaking in the report text improved

\section{Recommendation}

The success of the Classroom Action Research that the authors have done has brought success in improving English speaking skills through logico media. These results are expected to provide benefits and good references for teachers, students, schools and other writers. (1) It is expected that teachers can apply Logico media in helping to improve the four English skills, namely listening, speaking, reading and writing or in other relevant subjects, (2) Students are expected to always be active and always concentrate in participating in the teaching and learning process, so as to create conducive learning situations and conditions. Thus, the learning objectives can be achieved properly. (3) For 
further researchers, this research is expected to be a reference and reference for schools to carry out further research, so as to optimize efforts to improve the four English skills, namely listening, speaking, reading and writing. 


\section{REFERENCES}

Arikunto, Suharsini. (2008). Penelitian Tindakan Kelas. Jakarta: Bumi Aksara.

Azizah, R. (2019). Students' Ability in Writing Report Text of Grade XI at SMK Negeri 1 Painan. Jurnal Ilmiah Universitas Batanghari Jambi, 19(2). https://doi.org/10.33087/jiubj.v19i2.614

Batubara, M. H., Rahila, C. D. I., \& Rahmadani, P. (2021). AN ANALYSIS ON THE STUDENTS' ERROR IN WRITING REPORT TEXT AT EIGHT GRADE STUDENTS OF SMP N 6 TIMANG GAJAH. Jurnal As-Salam, 5(1). https://doi.org/10.37249/assalam.v5i1.237

Becker, C., \& Roos, J. (2016). An approach to creative speaking activities in the young learners' classroom. Education Inquiry, 7(1). https://doi.org/10.3402/edui.v7.27613

Conny, C., \& Devita, R. (2019). The Effect of Round Table Technique On Students' Ability In Writing Report Text of Nineth Grade Of SMP Pabaku Stabat In Academic Year 2018/2019. Jurnal Serunai Bahasa Inggris, 11(2). https://doi.org/10.37755/jsbi.v11i2.146

Dinamika, S. G., \& Hanafiah, R. (2019). SYNTACTICAL ERROR ANALYSIS ON REPORT TEXT. JOALL (Journal of Applied Linguistics \& Literature), 4(2). https://doi.org/10.33369/joall.v4i2.7681

Djumingin, S. (2017). The Practice of Lesson Study Model in Teaching Writing Report Text. Journal of Education and Learning (EduLearn), 11(1). https://doi.org/10.11591/edulearn.v11i1.4315

Florentina Robert, N., \& Syahtia Pane, W. (2020). Teacher's Strategies in Teaching English Speaking to Young Learners. Borneo Educational Journal (Borju), 2(2). https://doi.org/10.24903/bej.v2i2.627

Muftiani, N. (2015). MOTIVATING FACTORS OF STUDENTS' READING REPORT TEXT IN READING EXPLORER BOOK AS LEARNINGSOURCE FOR THE 7 th GRADE OF SMP NASIONAL 3 BAHASA PUTERA HARAPAN PURWOKERTO. Exposure Journal, 4(2).

Owen, E. A., Razali, A. B., Samad, A. A., \& Noordin, N. (2019). Enhancing Libyan students' english speaking performance through language game and information gap activities. Problems of Education in the 21st Century, 77(1). https://doi.org/10.33225/PEC/19.77.110

Pujianto, D., Emilia, E., \& Sudarsono, M. I. (2014). A process-genre approach to teaching writing report text to senior high school students. Indonesian Journal of Applied Linguistics, 4(1).

https://doi.org/10.17509/ijal.v4i1.603

Purnamu, C. H. E., \& Priyana, J. (2020). Improving the speaking learning process to the students of grade VIII through games. Lingua Pedagogia, Journal of English Teaching Studies, 2(1).

https://doi.org/10.21831/lingped.v2i1.23751

Rahmi, Y., \& Ratmanida. (2014). The use of discovery learning strategy in teaching reading report texts to senior high school students. Journal of English Language Teaching, 3(1).

Rizky, R., \& Zainil, Y. (2021). The Use of the Bits and Pieces Game on Students' Achievement on Writing Report Text. AL-ISHLAH: Jurnal Pendidikan, 13(1). https://doi.org/10.35445/alishlah.v13i1.463

Signes Gregori, C. (2015). Robin Digital Education Review-Number 30. Journal on English as a Foreign Language, 2(1). 
Srinivas, P. R. (2019). The Importance of Speaking Skills in English Classrooms. Alford Council of International English \& Literature Journal (ACIEL), Vol 2(Issue 2).

Yulianti, E., \& Setiawan, E. (2019). IMPROVING STUDENTS' READING COMPREHENSION THROUGH RECIPROCAL TEACHING STRATEGY ON REPORT TEXT. PROJECT (Professional Journal of English Education), 2(5). https://doi.org/10.22460/project.v2i5.p601-607

Zuhriyah, M. (2017). Storytelling to improve students' speaking skill. Jurnal Tadris Bahasa Inggris. 